\title{
WORKPLACE ACCIDENTS IN BRAZIL: ANALYSIS OF PHYSICAL AND PSYCHOSOCIAL STRESS AND HEALTH-RELATED FACTORS
}

\author{
SIMARLY M. SOARES ${ }^{1}$ \\ (iD) https://orcid.org/0000-0002-6098-289X \\ SIMONE GELMINI ${ }^{1}$ \\ (iD) https://orcid.org/0000-0003-4081-5362 \\ SILVÂNIA S. S. BRANDÃO \\ (iD) https://orcid.org/0000-0002-1466-5543 \\ JUNE M. C. SILVA ${ }^{1}$ \\ (iD) https://orcid.org/0000-0002-3642-5970
}

To cite this paper: Soares, S. M., Gelmini, S., Brandão, S. S. S., \& Silva, J. M. C. (2018). Workplace accidents in Brazil: Analysis of physical and psychosocial stress and health-related factors. Revista de Administração Mackenzie, 19(3). doi:10.1590/1678-6971/eRAMG170131

Submission: Dec. 18, 2017. Acceptance: Apr. 11, 2018.

1 Universidade Estadual de Montes Claros (Unimontes), Montes Claros, MG, Brazil.

2 Fundação Cultural Dr. Pedro Leopoldo, Pedro Leopoldo (FPL), MG, Brazil.

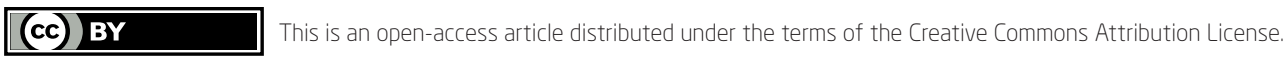

\footnotetext{
This paper may be copied, distributed, displayed, transmitted or adapted if provided, in a clear and explicit way, the name of the journal, the edition, the year and the pages on which the paper was originally published, but not suggesting that RAM endorses paper reuse. This licensing term should be made explicit in cases of reuse or distribution to third parties. It is not allowed the use for commercial purposes.

Este artigo pode ser copiado, distribuído, exibido, transmitido ou adaptado desde que citados, de forma clara e explícita, o nome da revista, a edição, o ano e as páginas nas quais o artigo foi publicado originalmente, mas sem sugerir que a RAM endosse a reutilização do artigo. Esse termo de licenciamento deve ser explicitado para os casos de reutilização ou distribuição para terceiros. Não é permitido o uso para fins comerciais.
} 


\section{ABSTRACT}

Purpose: To identify the influence of physical and psychosocial stress and health-related factors on the occurrence of work-related accidents, based on the National Health Survey (NHS) conducted in Brazil in 2013, through the execution of a retest in the Brazilian context, according to the model elaborated by Rommel, Varnaccia, Lahmann, Kottner, and Kroll (2016).

Originality/value: Brazil has a high rate of workplace accidents. This retest, applied to the Brazilian context based on the German model of Rommel et al. (2016), allows obtaining information concerning the factors that may increase the chances of workplace accidents.

Design/methodology/approach: Study with secondary data collected from the National Health Survey (Fiocruz, 2013). The model of Rommel et al. (2016) was used with the set of four blocks of variable factors. Logistic regression explored the physical, psychosocial, and healthrelated stress factors that may be more likely to occur in the workplace. Findings: $2.8 \%$ of the individuals have been involved in some work accident. Model 5 is the most explanatory of occupational accidents and factors such as high school level of education $(\mathrm{OR}=2.082)$, full-time work $(\mathrm{OR}=4.814)$, having three or more jobs $(\mathrm{OR}=2.593)$, exposure to radiation, asthma $(\mathrm{OR}=4.880)$, and alcohol consumption $(\mathrm{OR}=$ 4.620), according to each block typified, which most significantly increase the chances for the occurrence of work accidents. Managers and legislators should observe the factors that increase the chances of an accident occurring in order to develop prevention policies or actions.

\section{KEYWORDS}

Workplace accidents. Physical stress. Psychosocial stress. Health-related factors. Occupation. 


\section{INTRODUCTION}

Workplace accidents have always been part of society. Although they are fatalities and represent deviations from normality, not all are avoided. However, it is opportune to investigate this subject so as to discover the factors that may interfere with the routine of individuals and increase the chances of such accidents occurring. The interest in the subject has grown in the scientific literature, and a possible reason for the expansion of research is its negative impact on the well-being of employees and, consequently, on the operations carried out by organizations.

Even in developed countries, this subject remains an object of studies and concern on the part of organizations. The National Census of Fatal Occupational Injuries (Bureau of Labor Statistics, 2016) pointed out that the overall rate of fatal injury for workers in 2015 was 3.38 per 100,000 full-time equivalent workers. What draws attention is that the annual total of 4,836 fatal workplace injuries in 2015 was the highest since 5,214 fatal injuries in 2008. In this context, the groups with the highest fatality rates were: "Agriculture, forestry, fishing, and hunting", with 22.8 deaths per 100,000 workers; "Transportation and warehousing", with 13.8; "Mining, quarrying, and oil and gas extraction", with 11.4; and "Construction" with 10.1 .

On the other hand, Germany recorded about 1 million notifiable workrelated accidents per year (Rommel et al., 2016). As for Brazil, the country has a negative image due to its high rate of work accidents. The statistics indicate that there are three fatalities every two hours and three non-fatal work-related accidents per minute (Cavalcante et al., 2015). In the same direction, statistics indicate that in Brazil, in 2013, the date of the last update of the social security statistical yearbook, the National Institute of Social Security (INSS) spending with compensations for injured workers reached 367 million BRL in benefits for work accidents, totaling 717,900 notified work accidents. Consequently, the most frequent incidents are bone fractures, sprains, amputations, and other injuries, followed by Repetitive Strain Injuries and Work-Related Musculoskeletal Disorders (RSI/ WRMSDs), followed by mental and behavioral disorders, such as depressive episodes, stress, and anxiety.

The occurrence of occupational accidents constitutes a severe problem for the victim, the company, and society. There are financial, social security, productivity, legal, psychological, and social consequences. According to 
Guimarães and Grubits (2004), the implications for individuals also result in psychiatric-psychological changes and affect the employee's morale, as well as family, social, and professional aspects, which, in turn, compromise their life projects. As for the companies, occupational diseases and accidents lead to productivity losses, increase absenteeism, increase health care costs, and affect the company's image in society.

In this scenario, where such an event has consequences for all parties involved, the challenge is to create conditions to maintain the physical and mental health of employees, in order to protect them from the risks to health and from the stress associated with the performance of their duties and the physical environment where the work activity is performed. Therefore, the theme is relevant because it encompasses the interests of workers, managers, and legislators, by making it possible to understand the factors that affect the workers' health and the stress factors that can lead to work accidents.

In this sense, the primary purpose of this study is to retest the five models of Rommel et al. (2016), in the Brazilian context, so as to analyze the physical and psychosocial stress and health-related factors for the occurrence of work-related accidents, from data obtained in the NHS carried out in 2013 in Brazil (Fiocruz, 2013). To this end, this paper is divided into four sections. The first section presents the theoretical framework on workplace accidents, as well as physical and psychic stress and health-related factors. The second section discusses the methodology and the design of the models used in this research. The third section presents the results. The fourth and last section presents the conclusions, as well as the limitations of this research.

\section{HEORETICAL FRAMEWORK}

\subsection{The workplace accidents}

The Industrial Revolution brought significant changes to society and also impacted on work-related accidents, as the risks to people's health increased and diversified. If accidents with mine workers were common and prevalent before the process of industrialization, the accidents then migrated to the construction sector, where its incidence increased (Fahel, 2003; Areosa \& Dwyer, 2010). From this perspective, a study by Liberty Mutual revealed that companies saved up to three dollars for every dollar invested in workplace safety. Therefore, investing in prevention can reduce the incidence of accidents and, consequently, reduce expenses with medical treatment, compensations, and fines (Snell \& Bohlander, 2009). 
It is appropriate to point out that the terms "injury" and "accident" are closely related. An injury is a trauma, damage, or wound, whereas an accident is an abnormality or loss of process control leading to an incident or accident. Although not every accident causes an injury, every injury results from an accident (Khanzode, Maiti, \& Ray, 2012). Therefore, the concept used for this study is that of "occupational accident."

In view of this, we observe that the relationship between health and occupational safety is elementary and even legislative. In Brazil (1991), Law n. 8.213 of July 24, 1991, Art. 19, defines an occupational accident as that which occurs in the workplace and causes bodily injury or functional impairment, resulting in death, or permanent, or temporary reduction of one's work capacity. Since accidents are harmful to people's lives, the Brazilian government approved the Order n. 3.214, through the Ministry of Labor, to standardize the procedures of occupational safety and medicine to be observed by private, public and government agencies. In this respect, each standard has minimum parameters and instructions for mandatory procedures according to each activity or function performed, in order to prevent accidents and diseases caused or aggravated by the labor activity (Macedo, 2008).

From this, accidents can be classified as typical accidents, arising from the "characteristic of the professional activity performed by the one injured"; commuting accidents, which occur "on the way between the residence and the workplace and vice versa"; or work-related illnesses caused by "any type of occupational disease peculiar to a certain branch of activity provided for by the Social Security table" (Ministério da Fazenda, 2015, p. 554). Regarding the types of disabilities caused by accidents, temporary disability is considered to include insured workers who were temporarily incapacitated for the exercise of their labor activity due to accidents or occupational diseases. In these terms, permanent disability refers to the insured workers who have become permanently incapacitated for work. This can be of two types: partial or total. They refer to definitive sequela and to the reduction of labor capacity and total disability for any labor activity, respectively (Ministério da Fazenda, 2015, p. 554).

In the organizational environment, workers are exposed to risks arising from the workplace setting or the execution of their activities, which according to the intensity of time of exposure can cause work-related accidents and diseases (Cavalcante et al., 2015). Physical hazards may include noise, radiant heat, humidity, cold, abnormal pressures, ionizing and non-ionizing radiation, among others. Chemicals are hazardous because 
they refer to substances that can harm the body through the airways, such as dust, gases, and vapors. Biological hazards involve fungi, bacteria and parasites found, for example, in hospital environments. Mechanical hazards refer to a company's equipment, installation, and operation conditions. Finally, ergonomic risks involve awkward postures or efforts exerted in the execution of activities such as shift work, excessive workload, and repetition of activities (Rodrigues \& Santana, 2010).

Under Brazilian law, in the event of an accident, the company has the responsibility to pay the employee his full salary during the first 15 consecutive days of leave of absence. After this period, it is up to the social security medical expert examination, after the claim, to evaluate the worker's condition for the grant of disability insurance. There are cases in which the Social Security Institute already "takes responsibility for the payment from the date of the accident, as a single worker and special category workers under social security" (Ministério da Fazenda, 2015, p. 554). Therefore, companies need to maintain a healthy environment to ensure the well-being and quality of life of their workers.

From the perspective of analyzing several factors in an associated manner, Rommel et al. (2016) indicate that three dimensions must be observed: occupation, working conditions (physical and psychosocial), and health-related factors. They consider that these three dimensions are not independent when it comes to occupational injuries. In fact, it is necessary to analyze their effects in view of their dependence.

\subsection{Physical and psychosocial stress and health- related factors}

Stress is a subject of study in several contexts and is associated with several variables. In the organizational environment, stress is a process in which the work demands are perceived by the individuals as excessive. They consequently lead to adverse reactions because they are characterized as stressors (Paschoal \& Tamayo, 2004). These adverse reactions are the physical, mental, and physiological responses that translate into negative responses. The authors recommend that this concept of occupational stress is based on "organizational stressors, individual responses, or the various variables present in the stress-response process" (Paschoal \& Tamayo, 2004, p. 46). These three aspects are characterized by Jex (1998) as 1. stressful stimuli in the workplace setting that require adaptive responses from the individual, yet at a level that extrapolates their ability; 2. physiological and 
behavioral responses to stressful events; 3. stress-response stimuli that characterize the demands process with an impact on employees.

Factors such as lack of physical structure to perform work activities and high work demand are examples of stressors. Organizational stressors can be defined as having a psychosocial nature, representing aspects such as interpersonal relationships, role ambiguity, autonomy, work under pressure, extended work hours, and career development factors. They can also be of a physical nature, such as aspects related to infrastructure, ventilation, lighting, among others (Paschoal \& Tamayo, 2004). Such situations can impact the individual's health by generating responses such as anxiety, dissatisfaction, and depression. And this emotional imbalance, in addition to reducing the worker's income, makes him susceptible to the occurrence of workplace accidents.

Research seeks to relate factors that cause or are associated with injuries and accidents, such as the type of occupation, as well as physical or psychosocial, socio-demographic or health factors (Rommel et al., 2016). Sometimes these studies seek to associate accidents with a specific factor, or they make multiple associations; when it comes to gender, many studies indicate the prevalence for men, who have higher incidence rates of physical injuries than women. In turn, women showed higher rates of mental disorders than men (Berecki-Gisolf, Smith, Collie, \& McClure, 2015). Yet, this does not decharacterize the need of care for both genders, mainly because those surveys were carried out with the participation of specific groups and samples in different contexts. In this context, manual workers are more exposed to accidents (Piha, Laaksonen, Martikainen, Rahkonen, \& Lahelma, 2012). In addition, the occurrence of accidents and injuries does not depend on the size of a company. In fact, small businesses, which occasionally fail to comply with adequate legislation by implementing security procedures, are prone to having a high incidence rate (Pedersen, Hannerz, Christensen, \& Tüchsen, 2011).

Indeed, since the creation of the International Labor Organization (ILO), in 1919, preventive measures have been created concerning work schedule, unemployment, maternity leave, night shifts for underage workers and women, the minimum age for admission of children, among other aspects. From that moment onwards, there was a stimulus for the implantation of occupational medicine services with expert doctors to assist companies, as well as the insertion of engineers, both with the purpose of guaranteeing the physical integrity and health of workers, in a scenario in which deaths and mutilations were common. These measures aimed to contribute to better living conditions for workers and to the preservation of their lives. 
A study (Dembe, Erickson, Delbos, \& Banks, 2005) conducted with German workers investigated whether prolonged hours increased the risk of occupational injuries. It identified that the risks of non-fatal and fatal work accidents increased after the eighth hour (Dembe et al., 2005). This implies that workers exposed to more extended work hours are subject to the occurrence of work accidents, in view of their physical and emotional exhaustion. In turn, shift work is the one with irregular schedules, if considered the usual standards, that is, daytime activities. In this case, some studies have indicated that, as a result of breaking out of the routine, this type of activity can cause disruption and accidents or injuries at work (Wong, McLeod, \& Demers, 2011).

Therefore, to analyze work accidents, it is necessary to consider both, the individual factors and those concerning the work activity (Alali et al., 2017). This is because it is already a consensus that an environment with poor working conditions, physical and mental load and stress increases the chances of accidents. There are even indications that workplace autonomy is beneficial to the well-being and productivity of workers, hence the countries' concern about the need to improve working conditions (Lun Lu et al., 2014). Based on these studies, we postulate the following hypothesis:

H1: Workers experiencing physical and psychosocial stress are more likely to suffer work-related injuries than those who are not.

In the scope of health, the threats are, in fact, occupational diseases and work-related diseases. In this aspect, despite being related to the same context, they have different definitions. Occupational diseases are specifically caused by some activity or occupation performed by the worker. On the other hand, work-related diseases are additional to occupational diseases and occur in the absence of ideal or consistent conditions of hygiene practices. Therefore, associated diseases can impact workers in the long run. Examples include cancer, asthma or pneumonia in retired people who worked in environments with polluted and toxic air (Mascarenhas et al., 2015).

In the mid-1980s and 1990s, a new phenomenon emerged: the musculoskeletal disorders, repetitive strain injuries (RSIs), and work-related musculoskeletal disorders (WMSDs), that affected workers in various segments (Mascarenhas et al., 2015). The use of manual force and the adoption of inappropriate postures in performing labor activities are some of the factors that cause such affections. In this circumstance, the symptoms are perceived by the limitation of movement, cramps, among other aspects 
that influence the temporary or permanent disability of the employee to perform his work (Duarte et al., 2012).

A habit that can increase the quality of life of workers in the face of problems caused by work activities is the practice of physical activities, as active individuals can reduce the risk of injuries (Pan, Schernhammer, Sun, \& Hu, 2011; Lun Lu, Nakata, Park, Naomi, \& Swanson, 2014; Dong, Wang, \& Largay, 2015). However, many workers have not yet realized that such a practice can benefit their overall health. Another risk factor is obesity, for this prevalence can lead to other diseases that directly affect the worker's performance, such as diabetes, hypertension, back pain, among others (Paixão, Paixão \& Franco, 2009).

Added to this, individual behavior also influences the occurrence of accidents. Therefore, the use of alcohol and drugs brings risks to the person's life and damages to the public management, in view of the expenses caused by the harmful consequences to the health of individuals. It must be considered that an individual who is under the effect of alcohol and drugs in his workplace is more prone to unsafe acts that can lead to work accidents due to lack of attention or loss of reflexes. The use of tobacco and its byproducts leads to a variety of diseases, increases absence in the workplace and is also associated with mortality and morbidity (Lotufo, 2007). So, the use of alcohol, drugs, and tobacco can lead to the occurrence of work accidents, illnesses, withdrawals, and reduction of productivity. Therefore, the use of alcohol, drugs, or cigarettes may be associated with accidents (Chau, Bhattacherjee, Kunar, \& Lorhandicap, 2009).

Then, with these and other prevalence, there was a need to assess the health of workers as for its organizational, ergonomic and psychosocial aspects since the risks were not restricted only to physical accidents. This leads to the analysis of health-related factors that contribute to the explanation of work accidents, as postulated by Hypothesis 2. Hence:

$\mathrm{H} 2$ : Health-related factors contribute to the explanation of occupational accidents when the type of occupation is considered.

The health-related factors can be aggravated if they are associated with scenarios of extended work hours, multiple jobs, or extended workload. This affects the workers' health, leading to problems such as hypertension, muscle pain, stress, among others.

Although there is demand, shift work can increase the risk of diabetes, obesity and various cancers due to behavioral deregulation. (Pan et al., 2011; Alali et al., 2017). That said, the insertion of the presented hypotheses is justified. 


\section{MATERIAL AND METHODS}

For this study, we used secondary data collected from the National Health Survey (NHS) conducted in 2013 in Brazil (Fiocruz, 2013). In this paper, we proposed to retest the five models of Rommel et al. (2016) in the Brazilian context, so as to analyze the physical and psychosocial stress and health related-factors based on the NHS. The perspective of analysis following the German model, considering its scale, can contribute to a clearer understanding of the universe of occupational accidents. For this reason, we tested the same set of four blocks elaborated by the author as "variable factors," based on the German Health Update 2010 (Rommel et al., 2016), but this time applied to the Brazilian NHS of 2013 (Fiocruz, 2013). These factors will be explained later.

For such work, it is necessary to clarify that the NHS is a household survey and a part of the Brazilian Integrated Home Inspection System (SIPD). Its scope is national, under the responsibility of the Ministry of Health (MS), in partnership with the Brazilian Institute of Geography and Statistics (IBGE). In this survey, the collection of information has three axes: health conditions; health care (access, utilization, continuity of care, and financing); and surveillance of diseases and health problems and associated risk factors (Damacena et al., 2015; Szwarcwald et al., 2014).

The investigation consists of a three-part questionnaire: the household, the residents, and the individual questionnaires. The first two are answered by a resident of the household who knows how to inform about the socioeconomic and health situation of all other residents. In turn, the individual part is answered by a resident, aged 18 or older. Medical assessments were also performed with the selected adult, such as weight, height, and urine and blood collection. As it is a public database, the questionnaire model, contextualization, theoretical framework and other research information are available on the NHS website (Fiocruz, 2013; Damacena et al., 2015; Szwarcwald et al., 2014).

The survey sample is defined as a three-stage cluster: the census layers or set of layers make up the primary sampling units, households are the second stage units, and residents aged 18 or older define the third stage units. For this study, the sample size was calculated with $95 \%$ confidence intervals, the number of households visited amounted to 81,167 , with 64,348 home interviews; the response rate was $91.9 \%$, and the loss rate was $20.8 \%$. On the other hand, the interview with adults aged over 18 included $(n=60,202)$ had a response rate of $86 \%$ and a loss rate of $25.9 \%$. This was the sample considered for this study (Damacena et al., 2015; Szwarcwald et al., 2014). 
As in the model elaborated by Rommel et al. (2016) for the analysis of physical and psychosocial stress and health-related factors, the design of this research considered the occurrence of work accidents in Brazil as a dependent variable. In this direction, it was evaluated by the following question in the NHS: "In the last 12 months, were you involved in a work accident?". The response was dichotomized as "no" (1) and "yes" (2). The inclusion criteria were: age between 18 and 70, having worked in the last 12 months, having received compensation, and having been (or not having been) involved in a work accident.

In turn, the independent variables also followed the model of Rommel et al. (2016) and were organized in blocks of factors that can present the chances for the occurrence of work accidents: 1. basic factors; 2 . type of occupation; 3. work-related stress indicators; and 4. health-related factors. Block 1 consists of individual profile variables, applied to the five analytical models. Block 2 consists of the variables of the occupational group for the purpose of testing the comparison between the occupation groups, with the application of the Chi-square test of likelihood. In turn, blocks 3 and 4 represent constructs related to the hypotheses postulated in this research.

To apply of the model of Rommel et al. (2016) to the Brazilian context and the comparison between the German and Brazilian environments, the questions in the NHS (2017) which correspondence was not possible in relation to those proposed by GEDA (2010) were excluded. In the other cases where adjustments were possible, these were detailed in the typification of each of the analysis blocks. The variables are presented in Table 3.1.

In block 1, age was categorized by the lower quartile (age 30) and median (age 38) as reference for the three categories for multivariate analysis (18-30, 31-38, 39-70), and in five categories for the descriptive analysis (18$29,30-39,40-49,50-59,60+)$, in order to facilitate the procedure. Other variables in block 1, such as work schedule, are based on the Brazilian legislation that estimates the regular weekly workload up to a maximum of 44 hours. Hence, level of education, work schedule (0, 1 and 2$)$, and number of jobs (1, 2 and 3). The model of Rommel et al. (2016) did not contemplate the variable level of education but was used in this research, as it was essential to identify if the factor of instruction reflected in higher chances of accidents, considering that, in the classification of occupations used in Germany, the level of education is implied. Unlike the Brazilian reference, the Brazilian Classification of Occupations (CBO) foresees ten occupational groups, classified by level of competence and similarity to the activities presented in Table 3.1. 
The physical and psychosocial stress variables of block 3 respond to $(1=$ no; 2 = yes) and the variables "bad working climate" and "job uncertainty" were not included in this study because they were not part of the NHS database. Regarding block 4, this model follows the model of 3, except for obesity, which was evaluated from the body mass index (BMI) which, according to the World Health Organization (2016), is calculated by the following formula: current weight $(\mathrm{kg}) /$ height $(\mathrm{m})^{2}$, where 18.5-24.9 is considered normal, $<18.5$ is underweight, and $\geq 25$ is overweight/obese (Associação Brasileira para o Estudo da Obesidade e da Síndrome Metabólica, 2009). In the case of diabetes, considering that in the general sample we found that $0.04 \%$ of pregnant women were diagnosed during pregnancy and, because it was a low value, it was included, the responses were considered positive. Self-assessed health was classified as "very good," "good" and "fair" (yes), as well as "poor" and "very poor" (no).

\section{(Table 3.1)}

\section{TYPIFICATION OF PHYSICAL AND PSYCHOSOCIAL STRESSORS AND HEALTH-RELATED FACTORS (ROMMEL ET AL., 2016)}

\begin{tabular}{|c|c|c|c|}
\hline $\begin{array}{l}\text { Block } 1 \text { - Basic } \\
\text { Factors }\end{array}$ & Block 2 - Occupation & $\begin{array}{l}\text { Block } 3 \text { - Work-Related } \\
\text { Stress Indicators }\end{array}$ & $\begin{array}{c}\text { Block } 4 \text { - Health-related } \\
\text { Factors }\end{array}$ \\
\hline Gender & Occupational Group & Physical Stress & Behavioral Risk Factors \\
\hline Women / Men & Armed Forces, policemen and & Exposure to chemicals & Physical activity <=weekly \\
\hline Age & firefighters & Exposure to noise & hours \\
\hline $18-30$ & Senior officials and members, & Long exposure to sunlight & Smokes daily \\
\hline $31-38$ & managers of & Exposure to radiation & Alcohol consumption \\
\hline $39-70$ & public interest organizations & Exposure to urban waste & Normal weight \\
\hline Levei of Education & and managers & Exposure to biological materiais & Underweight (obesity) \\
\hline Primary school & Science and arts & Exposure to industrial dust & Overweight (obesity) \\
\hline High school & Mid level technicians & Heavy-carrying & Chronic Conditi ons \\
\hline Bachelor's degree or & Administrative services & Psychosocial stress & Depression \\
\hline higher & Services, sales clerks & Work under pressure & Diabetes \\
\hline Work Schedule & Farming, fishing and forestry & Shift work & Coronary disease \\
\hline Half-time & Goods-producing industries & & Asthma \\
\hline Full-time & (crafts) & & WMSD \\
\hline Extended hours & $\begin{array}{l}\text { loods-producing industries } \\
\text { (machine operators) }\end{array}$ & & Chronic back pain \\
\hline Number of Jobs & Maintenance and repair & & Self-rated health \\
\hline One & & & Overall health \\
\hline TwO & Do you carry out crafts & & \\
\hline Three or more & activities? & & \\
\hline $\begin{array}{l}\text { Professional } \\
\text { Experience }\end{array}$ & $\begin{array}{l}\text { Targeted at machine operators } \\
\text { (MLE) }\end{array}$ & & \\
\hline
\end{tabular}


For the statistical analysis, the data were organized by using the software called Statistical Package for the Social Sciences (Version 20.0). As a tool for analysis, we resorted to logistic regression, dichotomously attributing to the DV "one" 1 . For individuals who have never suffered accidents at work and "two" 2. For those who have. Subsequently, descriptive analysis, multicollinearity analysis, and correlation matrix were performed. At that point, the variable occupational group was used only as a control variable $(\mathrm{CV})$ to create interactions with the others, despite the model proposed by Rommel et al., 2016.

For the descriptive analysis, we transformed the sampling plan into a population estimate ( $\mathrm{n}$ Expanded $\mathrm{x}$ 1,000). To investigate the association between work-related accidents and associated factors, multivariate logistic regression modeling techniques were applied. The models 1, 2, 3, 4 and 5 were calculated by including the blocks that make up each model, namely: blocks 1 and 2 (model 1), blocks 1 and 3 (model 2), blocks 1 and 4 (model 3), blocks 1, 2 and 3 (model 4) and model 5, which included all variables. For the prevalence, we used a $95 \%$ confidence interval (95\% CI). To check the adjustment of the model and test the explanatory power, we resorted to the pseudo-R-squared (Nagelkerke's $\mathrm{R}^{2}$ ) in order to analyze the model's ability to explain the proportion of variance.

\section{RESULTS}

Before the modeling, the Chi-square test was performed to verify if the dependent variables were associated with the dependent variable. In this case, the results showed a low level of relationship among the variables, which may indicate the absence of problems concerning multicollinearity (chi-square $=0$ ), according to Hair Jr., Black, Babin, Anderson, and Tatham (2005).

Consequently, the descriptive analysis was presented in Table 4.1. In this part of the study, the initial criteria were minimum (18) and maximum age (70); having worked in the previous 12 months; having (or not having) been involved in a work accident; and having received remuneration during that same period. In addition, the sampling plan was transformed into a population estimate for a better understanding of the data.

According to data presented in Table 4.1, 2.8\% of the individuals according to criteria and inclusion had already been involved in some work accident. The sample consisted of men (48.4\%) and women (51.6\%). The prevalent age was $18-29$ years $(24.9 \%)$, and the level of education was 
elementary school (41.7\%). About $4.7 \%$ had multiple jobs, considering two, three or more, and $27.6 \%$ worked long hours, that is, workloads exceeding 44 hours a week.

As for the occupational groups, service workers and sales clerks accounted for $20.2 \%$, followed by maintenance and repair workers (19.6\%) and, less significantly, the group including the armed forces, policemen, and firefighters $(0.6 \%)$, according to Table 4.1 .

\section{(Table 4.1)}

SAMPLING CHARACTERISTICS, GAINFULLY EMPLOYED MEN AND WOMEN

\begin{tabular}{|c|c|c|c|c|c|}
\hline Variables & $\%$ & $\begin{array}{c}n \text { Expaided } \\
(\times 1,000)\end{array}$ & Variables & $\%$ & $\begin{array}{c}n \text { Expaided } \\
(\times 1,000)\end{array}$ \\
\hline Has been involved in an & & & Number of Jobs & & \\
\hline accident & 2,8 & 1.297 & One & 95,30 & 35.248 \\
\hline Gender & & & Two & 4,10 & 1.510 \\
\hline Male & 48,4 & 22.318 & Three ormore & 0,60 & 210 \\
\hline Age & & & Occupational Groups & & \\
\hline $18-29$ & 24,9 & 11.501 & Arme d Forces, policemen and & & \\
\hline $30-39$ & 27 & 12.463 & firefighters & 0,60 & 197 \\
\hline $40-49$ & 22 & 10.132 & Senior officials and members, managers & & \\
\hline $50-59$ & 16,8 & 7.741 & $\begin{array}{l}\text { of public interest organizations and } \\
\text { managers }\end{array}$ & 580 & 2127 \\
\hline $60+$ & 9,3 & 4.276 & $\begin{array}{l}\text { managers } \\
\text { science and arts nrofessionals }\end{array}$ & $\begin{aligned} 5,80 \\
1,90\end{aligned}$ & $\frac{2.121}{4034}$ \\
\hline Levei of Education & & & Mid level technicians & $\frac{10,90}{8,30}$ & $\begin{array}{l}4.034 \\
3.085\end{array}$ \\
\hline Primary school & 41,7 & 16.728 & Administrative services workers & 7,60 & 2.798 \\
\hline High school & 39,2 & 15.727 & Services workers, sales cletks & 20,20 & 7.483 \\
\hline Bachelor's degree or higher & 19,1 & 7.656 & Farming, fishing and forestty workers & 5,80 & 2.138 \\
\hline Work Schedule & & & Goods-producing industries (crafts) & 12,70 & 4.687 \\
\hline Half-time & 12,00 & 4.437 & Goods-producing industries (machine & & \\
\hline Full-time & 60,40 & 22.321 & operators) & 8,60 & 3.162 \\
\hline Extended hours & 27,60 & 10.218 & Maintenance and repair workers & 19,60 & 7.262 \\
\hline
\end{tabular}

Note. Research Data.

Source: Elaborated by the authors.

Tables 4.2 and 4.3 showed the regression analysis results for the testing of the hypotheses $\mathrm{H} 1$ and $\mathrm{H} 2$. The first step of this analysis was the inclusion of control variables.

In model 1, the data presented in block 1 are statistically significant. Therefore, accidents are more likely to occur in the following situations: individuals employed in three or more jobs $(\mathrm{OR}=1.827)$, long hours (OR $=1.295)$, male $(\mathrm{OR}=1.048)$, and individuals with high school education 
level $(\mathrm{OR}=1.068)$. In block 2 , the occupational group "farming, forestry, fishing, and hunting" (OR $=9.827)$ and "handicraftsmen" $(\mathrm{OR}=6.788)$ surpass the other categories expressively.

Model 2 was composed of the basic factors and work-related stress indicators of, indicated an increased chance for those employed in three or more jobs ( $\mathrm{OR}=3.380)$, which is quite representative compared to workers with only one job. As in model 1, individuals with high school education prevailed. Therefore, the fact that those in the age range of 31-38 and 39-70 are less likely to be involved in accidents is attenuated. When inserting the variables of block 3 , we noticed a change in the chances of occurrence of accidents in relation to the gender of individuals; unlike model 1, we found that men are less likely to be involved in accidents compared to women $(\mathrm{OR}=$ 0.738). Regarding environmental risks, individuals who work in areas exposed to biological material had a higher probability of prevalence $(\mathrm{OR}=$ 2.390). In addition, efforts involving heavy carrying $(\mathrm{OR}=1.911)$ should also be analyzed, since they require caution from those who take part in such activities. As for the psychosocial stressors, working under pressure $(\mathrm{OR}=1.365)$ showed increased chances of occurrence, as opposed to shift work (OR $=0.927)$, when compared to night work, which is the reference for this analysis. The results of models 1, 2 and 3 are shown in Table 4.2.

\section{(Table 4.2)}

LOGISTIC REGRESSION ANALYSIS OF MODELS 1, 2 AND 3 FOR OCCUPATIONAL ACCIDENTS

\begin{tabular}{|c|c|c|c|c|c|c|c|c|c|}
\hline \multirow[t]{2}{*}{ Variables } & & \multicolumn{2}{|c|}{$\begin{array}{c}\text { Model } 1 \\
95 \% \text { C.I. to } \\
\text { EXP(B) }\end{array}$} & & \multicolumn{2}{|c|}{$\begin{array}{c}\text { Model } 2 \\
95 \% \text { C.I. to } \\
\text { EXP(B) }\end{array}$} & \multirow[b]{2}{*}{$\operatorname{Exp}(B)$} & \multicolumn{2}{|c|}{$\begin{array}{c}\text { Model } 3 \\
95 \% \text { C.I. to } \\
\text { EXP(B) }\end{array}$} \\
\hline & $\operatorname{Exp}(B)$ & LI & LS & $\operatorname{Exp}(B)$ & $\mathrm{LI}$ & LS & & $\mathrm{LI}$ & LS \\
\hline
\end{tabular}

Block 1 - Basic Factors

Gender

\begin{tabular}{llllllllll} 
Male & 1,048 & 1,043 & 1,053 & 0,738 & 0,730 & 0,746 & 1,674 & 1,657 & 1,692 \\
\hline Age & & & & & & & & & \\
$31-38$ & 0,880 & 0,875 & 0,885 & 0,339 & 0,334 & 0,334 & 1,036 & 1,024 & 1,048 \\
\hline $39-70$ & 0,770 & 0,766 & 0,775 & 0,599 & 0,591 & 0,606 & 0,824 & 0,814 & 0,834
\end{tabular}

Level of Education

\begin{tabular}{llllllllll} 
High school & 1,068 & 1,063 & 1,073 & 1,095 & 1,082 & 1,109 & 0,791 & 0,783 & 0,799 \\
\hline Bachelor's degree or higher & 0,721 & 0,714 & 0,727 & 0,720 & 0,707 & 0,732 & 0,279 & 0,275 & 0,283
\end{tabular}




\section{(Table 4.2 (continuation)) \\ LOGISTIC REGRESSION ANALYSIS OF MODELS 1, 2 AND 3 FOR OCCUPATIONAL ACCIDENTS}

\begin{tabular}{|c|c|c|c|c|c|c|c|c|c|}
\hline \multirow[t]{2}{*}{ Variables } & & \multicolumn{2}{|c|}{$\begin{array}{l}\text { Model } 1 \\
95 \% \text { C.I. to } \\
\text { EXP(B) }\end{array}$} & \multirow[b]{2}{*}{$\operatorname{Exp}(B)$} & \multicolumn{2}{|c|}{$\begin{array}{c}\text { Model } 2 \\
95 \% \text { C.I. to } \\
\text { EXP(B) }\end{array}$} & \multirow[b]{2}{*}{$\operatorname{Exp}(B)$} & \multicolumn{2}{|c|}{$\begin{array}{c}\text { Model } 3 \\
95 \% \text { C.I. to } \\
\text { EXP(B) }\end{array}$} \\
\hline & $\operatorname{Exp}(B)$ & $\mathrm{LI}$ & LS & & $\mathrm{LI}$ & LS & & LI & LS \\
\hline
\end{tabular}

Block 1 - Basic Factors

Work Schedule

\begin{tabular}{|c|c|c|c|c|c|c|c|c|c|}
\hline Full-time & 1,175 & 1,166 & 1,183 & 1,681 & 1,636 & 1,726 & 1,360 & 1,337 & 1,383 \\
\hline Extended hours & 1,295 & 1,284 & 1,305 & 1,630 & 1,587 & 1,675 & 1,292 & 1,269 & 1,315 \\
\hline \multicolumn{10}{|l|}{ Number of Jobs } \\
\hline Two & 1,793 & 1,777 & 1,808 & 0,851 & 0,835 & 0,867 & 2,068 & 2,034 & 2,102 \\
\hline Three or more & 1,827 & 1,782 & 1,874 & 3,380 & 3,271 & 3,493 & 2,556 & 2,455 & 2,662 \\
\hline Professional Experience & 1,004 & 1,004 & 1,005 & 0,990 & 0,989 & 0,990 & 0,997 & 0,996 & 0,997 \\
\hline \multicolumn{10}{|l|}{ Block 2 - Occupational Group } \\
\hline Senior officials and members & 1,845 & 1,688 & 2,017 & & & & & & \\
\hline Science and arts & 1,811 & 1,658 & 1,980 & & & & & & \\
\hline Mid level technicians & 3,617 & 3,311 & 3,951 & & & & & & \\
\hline Administrative services & 2,455 & 2,246 & 2,682 & & & & & & \\
\hline Services, sales clerks & 3,106 & 2,844 & 3,393 & & & & & & \\
\hline Farming, fishing and forestry & 9,827 & 8,995 & 10,735 & & & & & & \\
\hline $\begin{array}{l}\text { Goods-producing industries } \\
\text { (crafts) }\end{array}$ & 6,788 & 6,214 & 7,414 & & & & & & \\
\hline $\begin{array}{l}\text { Goods-producing industries } \\
\text { (machine operators) }\end{array}$ & 4,802 & 4,395 & 5,245 & & & & & & \\
\hline Maintenance and repair & 6,596 & 6,039 & 7,205 & & & & & & \\
\hline
\end{tabular}

Maintenance and repair

Block 3 - Work-Related

Stress Indicators

Physical Stress

Exposure to chemicals

$1,302 \quad 1,286 \quad 1,318$

Exposure to noise

$1,129 \quad 1,117 \quad 1,142$

Long exposure to sunlight

$\begin{array}{lll}1,253 & 1,237 & 1,270\end{array}$

Exposure to radiation

$\begin{array}{llll}1,613 & 1,579 & 1,647\end{array}$

Exposure to urban waste

$\begin{array}{lll}1,349 & 1,329 & 1,370\end{array}$

Exposure to biological materiais

$\begin{array}{lll}2,390 & 2,356 & 2,425\end{array}$

Exposure to industrial dust

$\begin{array}{lll}1,220 & 1,201 & 1,239\end{array}$

Heavy-carrying

$1,911 \quad 1,891 \quad 1,932$

Psychosocial Stress

Work under pressure

$\begin{array}{lll}1,365 & 1,350 & 1,380\end{array}$

Shift work

$0,927 \quad 0,913 \quad 0,941$




\section{(Table 4.2 (conclusion))}

\section{LOGISTIC REGRESSION ANALYSIS OF MODELS 1, 2 AND 3 FOR OCCUPATIONAL ACCIDENTS}

\begin{tabular}{|c|c|c|c|c|c|c|c|c|c|}
\hline \multirow[t]{2}{*}{ Variables } & \multirow[b]{2}{*}{$\operatorname{Exp}(B)$} & \multicolumn{2}{|c|}{$\begin{array}{c}\text { Model } 1 \\
95 \% \text { C.I. to } \\
\text { EXP(B) }\end{array}$} & \multirow[b]{2}{*}{$\operatorname{Exp}(B)$} & \multicolumn{2}{|c|}{$\begin{array}{l}\text { Model } 2 \\
95 \% \text { C.I. to } \\
\text { EXP(B) }\end{array}$} & \multirow[b]{2}{*}{$\operatorname{Exp}(B)$} & \multicolumn{2}{|c|}{$\begin{array}{l}\text { Model } 3 \\
95 \% \text { C.I. to } \\
\text { EXP(B) }\end{array}$} \\
\hline & & LI & LS & & $\mathrm{LI}$ & LS & & $\mathrm{LI}$ & LS \\
\hline \multicolumn{10}{|c|}{$\begin{array}{c}\text { Block } 4 \text { - Health-related } \\
\text { Factors }\end{array}$} \\
\hline \multicolumn{10}{|c|}{ Behavioral Risk Factors } \\
\hline \multicolumn{10}{|c|}{ Physical activity <= weekly } \\
\hline Smokes daily & & & & & & & 1,110 & 1,095 & 1,124 \\
\hline Alcohol consumption & & & & & & & 0,953 & 0,944 & 0,962 \\
\hline Underweight (obesity) & & & & & & & 0,246 & 0,230 & 0,263 \\
\hline Overweight (obesity) & & & & & & & 0,825 & 0,817 & 0,832 \\
\hline \multicolumn{10}{|l|}{ Chronic Conditions } \\
\hline Depression & & & & & & & 1,784 & 1,757 & 1,811 \\
\hline Diabetes & & & & & & & 1,397 & 1,369 & 1,424 \\
\hline Coronary disease & & & & & & & 0,610 & 0,592 & 0,628 \\
\hline Asthma & & & & & & & 3,546 & 3,497 & 3,596 \\
\hline WMSD & & & & & & & 0,793 & 0,773 & 0,815 \\
\hline Chronic back pain & & & & & & & 1,449 & 1,433 & 1,466 \\
\hline \multicolumn{10}{|l|}{ Self-rated health } \\
\hline Overall health & & & & & & & 0,933 & 0,903 & 0,964 \\
\hline Nagelkerke's R ${ }^{2}$ & & 0,041 & & & 0,084 & & & 0,078 & \\
\hline
\end{tabular}

Note: p value <0.05; 95\% confidence interval. Ref.: reference group.

Source: Elaborated by the authors.

As shown in Table 4.2, in model 3, by including health-related factors with the basic factors, we obtained some relevant data concerning health care, which deserves attention. Behavioral factors regarded as risky indicated that in the case of physical activity $(\mathrm{OR}=2.015)$, there seems to be a higher chance of accidents for those who are inactive. As for the chronic conditions, asthma seems to be the aspect that most significantly increases the chances $(\mathrm{OR}=3.546)$, while depression was another relevant factor $(\mathrm{OR}=1.784)$.

Model 4 consists of the basic blocks, the stress indicators, and the control variable $(\mathrm{CV})$. At this point, we emphasize that when inserting the occupational groups (CV), we did not calculate Exp (B) and, therefore, these 
values were not inserted in the table. In block 1, we reinforce that having multiple jobs leads to an increased chance of accidents, since those with three or more jobs showed ( $\mathrm{OR}=4.080)$, which is complemented by the risk of those working full-time $(\mathrm{OR}=1.573)$ or extended hours $(\mathrm{OR}=$ $1.478)$. When inserting the stress indicators, exposure to biological material $(\mathrm{OR}=2.689)$, heavy carrying $(\mathrm{OR}=1.728)$ and exposure to radioactivity $(\mathrm{OR}=1.689)$ were the variables that increased the chances most significantly. Regarding psychosocial stress, working under pressure $(\mathrm{OR}=1.499)$ was the most significant, according to Table 4.3 .

In model 5 , according to Table 4.3 , in view of the insertion of the four blocks of variables, according to the model proposed by Rommel et al. (2016), it implied an interaction that produced the most complex model, in relation to the others presented. From this perspective, the data presented are statistically significant. It is important to highlight that, for the purpose of understanding the interaction between the variables of this model, the occupational group was used only and exclusively as a control variable. Therefore, the chance that an accident occurs with individuals working long hours (odds ratio $=3.185$ ) is lower than for those working full time $(\mathrm{OR}=$ 4.814). Likewise, the risk for individuals with higher education (OR = $1.578)$ is reduced when compared to workers at high school education level $(\mathrm{OR}=2.082)$. Regarding age, individuals aged between 31-38 $(\mathrm{B}=-0.442)$ and 39-70 ( $B=-0.415)$ were unlikely to suffer an accident, as this group presents the negative beta. Thus, accidents are more likely to occur among individuals aged 18-30. Table 4.3 presents the results of models 4 and 5 .

\section{(Table 4.3)}

LOGISTIC REGRESSION ANALYSIS OF MODELS 4 AND 5 FOR OCCUPATIONAL ACCIDENTS

\begin{tabular}{|c|c|c|c|c|c|c|c|c|}
\hline \multirow[t]{2}{*}{ Variables } & \multicolumn{4}{|c|}{$\begin{array}{c}\text { Model } 4 \\
95 \% \text { C.I. to } \\
\text { EXP(B) }\end{array}$} & \multicolumn{4}{|c|}{$\begin{array}{c}\text { Model } 5 \\
95 \% \text { C.I. to } \\
\text { EXP(B) }\end{array}$} \\
\hline & $\operatorname{Exp}(B)$ & $\mathrm{LI}$ & LS & B & Sig. & $\operatorname{Exp}(B)$ & $\mathrm{LI}$ & LS \\
\hline
\end{tabular}

Block 1 - Basic Factors

Gender

\begin{tabular}{lllllllll} 
Male & 0,694 & 0,686 & 0,702 & $-0,284$ & 0,000 & 0,753 & 0,733 & 0,772 \\
\hline $\begin{array}{l}\text { Age } \\
31-38\end{array}$ & 0,336 & 0,331 & 0,341 & $-0,442$ & 0,000 & 0,643 & 0,626 & 0,660 \\
\hline $39-70$ & 0,616 & 0,608 & 0,624 & $-0,415$ & & 0,660 & 0,642 & 0,679 \\
\hline
\end{tabular}




\section{(Table 4.3 (continuation)) \\ LOGISTIC REGRESSION ANALYSIS OF MODELS 4 AND 5 FOR OCCUPATIONAL ACCIDENTS}

\begin{tabular}{|c|c|c|c|c|c|c|c|c|}
\hline \multirow[t]{2}{*}{ Variables } & \multicolumn{4}{|c|}{$\begin{array}{l}\text { Model } 4 \\
95 \% \text { C.I. to } \\
\text { EXP(B) }\end{array}$} & \multicolumn{4}{|c|}{$\begin{array}{l}\text { Model } 5 \\
95 \% \text { C.I. to } \\
\operatorname{EXP(B)}\end{array}$} \\
\hline & $\operatorname{Exp}(B)$ & $\mathrm{LI}$ & LS & B & Sig. & $\operatorname{Exp}(B)$ & $\mathrm{LI}$ & LS \\
\hline
\end{tabular}

Block 1 - Basic Factors

Level of Education

\begin{tabular}{lllllllll} 
High school & 1,196 & 1,181 & 1,211 & 0,733 & 0,000 & 2,082 & 2,014 & 2,152 \\
\hline Bachelor's degree or higher & 1,209 & 1,186 & 1,232 & 0,456 & 0,000 & 1,578 & 1,520 & 1,639 \\
\hline $\begin{array}{l}\text { Work Schedule } \\
\text { Full-time }\end{array}$ & 1,573 & 1,531 & 1,616 & 1,571 & 0,000 & 4,814 & 4,466 & 5,188 \\
\hline Extended hours & 1,478 & 1,438 & 1,519 & 1,159 & 0,000 & 3,185 & 2,953 & \\
\hline $\begin{array}{l}\text { Number of Jobs } \\
\text { Two }\end{array}$ & & & & & & & & \\
\hline Three or more & 0,878 & 0,862 & 0,895 & $-0,400$ & 0,024 & 0,960 & 0,927 & 0,995 \\
\hline Professional Experience & 4,080 & 3,942 & 4,223 & 0,953 & 0,000 & 2,593 & 2,440 & 2,754 \\
\hline
\end{tabular}

\section{Block 2 - Occupational Group}

\begin{tabular}{lll} 
Senior officials and members & 17,397 & 0,980 \\
\hline Science and arts & 16,838 & 0,980 \\
\hline Mid level technicians & 18,992 & 0,978 \\
\hline Administrative services & 18,507 & 0,979 \\
\hline Services, sales clerks & 18,812 & 0,978 \\
\hline Farming, fishing and forestry & 19,759 & 0,977 \\
\hline Goods-producing industries (crafts) & 18,460 & 0,979 \\
\hline Goods-producing industries (machine & 19,188 & 0,978 \\
\hline operators) & 18,690 & 0,978 \\
\hline Maintenance and repair & &
\end{tabular}

\section{Block 3 - Work-Related Stress Indicators}

Physical Stress

\begin{tabular}{lrlllllll} 
Exposure to chemicals & 1,268 & 1,253 & 1,284 & $-0,166$ & 0,000 & 0,847 & 0,826 & 0,869 \\
\hline Exposure to noise & 1,153 & 1,140 & 1,166 & $-0,257$ & 0,000 & 0,773 & 0,756 & 0,790 \\
\hline Long exposure to sunlight & 1,127 & 1,112 & 1,143 & 1,051 & 0,000 & 2,860 & 2,792 & 2,930 \\
\hline Exposure to radiation & 1,689 & 1,653 & 1,726 & 1,445 & 0,000 & 4,244 & 4,095 & 4,397 \\
\hline Exposure to urban waste & 1,343 & 1,322 & 1,364 & 0,520 & 0,000 & 1,683 & 1,629 & 1,738 \\
\hline Exposure to biological materiais & 2,689 & 2,650 & 2,729 & 0,582 & 0,000 & 1,789 & 1,740 & 1,840
\end{tabular}




\section{(Table 4.3 (conclusion)) \\ LOGISTIC REGRESSION ANALYSIS OF MODELS 4 AND 5 FOR OCCUPATIONAL ACCIDENTS}

\begin{tabular}{|c|c|c|c|c|c|c|c|c|}
\hline \multirow[t]{2}{*}{ Variables } & \multicolumn{4}{|c|}{$\begin{array}{c}\text { Model } 4 \\
95 \% \text { C.I. to } \\
\text { EXP(B) }\end{array}$} & \multirow[b]{2}{*}{ Sig. } & \multirow[b]{2}{*}{$\operatorname{Exp}(B)$} & \multicolumn{2}{|c|}{$\begin{array}{l}\text { Model } 5 \\
95 \% \text { C.I. to } \\
\text { EXP(B) }\end{array}$} \\
\hline & $\operatorname{Exp}(B)$ & $\mathrm{LI}$ & LS & B & & & LI & LS \\
\hline \multicolumn{9}{|c|}{ Block 3 - Work-Related Stress Indicators } \\
\hline Exposure to industrial dust & 1,232 & 1,212 & 1,252 & $-0,162$ & 0,000 & 0,850 & 0,820 & 0,881 \\
\hline Heavy-carrying & 1,728 & 1,709 & 1,748 & 0,095 & 0,000 & 1,099 & 1,071 & 1,129 \\
\hline \multicolumn{9}{|l|}{ Psychosocial Stress } \\
\hline Work under pressure & 1,499 & 1,483 & 1,516 & 0,258 & 0,000 & 1,294 & 1,267 & 1,323 \\
\hline Shift work & 0,951 & 0,937 & 0,966 & 0,674 & 0,000 & 1,962 & 1,912 & 2,013 \\
\hline
\end{tabular}

Block 4 - Health-related Factors

Benhavioral Risk Factors

Physical activity < = weekly hours

\begin{tabular}{lrrrrr}
\hline Smokes daily & 0,643 & 0,000 & 1,903 & 1,865 & 1,942 \\
\hline Alcohol consumption & 0,568 & 0,000 & 1,765 & 1,722 & 1,809 \\
\hline Underweight (obesity) & 1,530 & 0,000 & 4,620 & 4,504 & 4,739 \\
\hline Overweight (obesity) & 17,897 & 0,962 & 0,000 & & \\
\hline
\end{tabular}

Chronic Conditions

\begin{tabular}{|c|c|c|c|c|c|}
\hline Depression & $-0,597$ & 0,000 & 0,550 & 0,523 & 0,579 \\
\hline Diabetes & 1,128 & 0,000 & 3,090 & 2,968 & 3,218 \\
\hline Coronary disease & $0 \wedge 22$ & 0,000 & 1,380 & 1,288 & 1,477 \\
\hline Asthma & 1,585 & 0,000 & 4,880 & 4,713 & 5,052 \\
\hline WMSD & 0,047 & 0,000 & 1,049 & 0,996 & 1,104 \\
\hline Chronic back pain & $-0,510$ & 0,000 & 0,950 & 0,925 & 0,975 \\
\hline \multicolumn{6}{|l|}{ Self-rated health } \\
\hline Overall health & 0,262 & 0,000 & 1,299 & 1,177 & 1,434 \\
\hline Nagelkerke's $\mathrm{R}^{2}$ & & & & 0,246 & \\
\hline
\end{tabular}

Note: p value < 0,05; confidence interval 95\%; Ref.. reference group; (-) Indicates that there was no odds ratio when running the regression.

Source: Elaborated by the authors.

\section{DISCUSSION}

This study revealed the need to know the effects of the variables, as they are inserted in the models and interact with each other, in order to influence 
the occurrence and the risks of work accidents. This research found that $2.8 \%$ of the individuals, according to the inclusion criteria, had been involved in some work accident. In fact, the sample consisted of men (48.4\%) and women (51.6\%). To test the hypotheses $\mathrm{H} 1$ and $\mathrm{H} 2$, the five models were presented and, considering the latter, as they are more explanatory, we found that there are more chances for the occurrence of work accidents among workers with high school education level, than those working full-time or extended hours, including those who are employed in three or more jobs. Moreover, work-related indicators such as exposure to radiation or sunlight as well as shift work seem to accentuate the risks of work-related accidents. Finally, risky behaviors such as alcohol abuse and obesity may influence the incidence chances. In addition, health aspects such as asthma and diabetes showed a significant chance, which can also be confirmed as for self-rated health.

When analyzing the logistic regression, we observed that as the independent variables were inserted, Nagelkerke's $\mathrm{R}^{2}$ indicated an improvement of the model (according to data presented in Tables 2 and 3). Thus, the pseudo $\mathrm{R}^{2}$ increased for each model, which means that it became more explanatory: model $1\left(\mathrm{r}^{2}=0.041\right)$, model $2\left(\mathrm{r}^{2}=0.084\right)$, model 3 $\left(r^{2}=0.078\right)$, model $4\left(r^{2}=0.098\right)$, and model $5\left(r^{2}=0.246\right)$. This implies that the inclusion of all variable blocks, based on Rommel et al., (2016), was able to produce a significant proportion of variance explained in model 5 , that is, $24.6 \%$. Next, the discussions of the variables that make up each of the presented blocks are detailed, specifically regarding model 5 .

Starting from the variables of block 1 , some findings such as the predominance of work-related accidents in males, present in the study by Rommel et al. (2016), were not confirmed in this study. Another communitybased survey was conducted in the state of Bahia, in the capital Salvador, with 2,512 residents. It found that of the 628 workers who reported having suffered an accident, there was a predominance of women (64\%) for this specific case. Another research carried out in the state of Minas Gerais, in the capital Belo Horizonte, diagnosed that, among the victims, the WMSD particularly affected female workers. From this perspective, it is appropriate that the prevention policies are targeted at both males and females as the goal is to take care of the lives of workers in general.

As for the individuals aged 31-70, these have a smaller chance of getting involved in work-related accidents. Similarly, for each year of experience, the data seem to point out to a smaller chance of accidents among more experienced individuals (Santana, Araújo-Filho, Albuquerque-Oliveira, \& Barbosa- 
Branco, 2006; Rommel et al., 2016; Malta et al., 2017). As for the work schedule, this variable was preponderant for those working full-time or long hours. Although people with multiple jobs $(4.7 \%)$ are few in the sample surveyed, this group showed a high risk $(\mathrm{OR}=2.593)$. Therefore, excessive hours worked can lead to exhaustion and cause fatigue, stress, negative influence performance and increase the chances of accidents among workers (Dembe et al., 2005). Rommel et al. (2016) did not find the influence of extended work hours in the occurrence of accidents and therefore suggested a more detailed analysis regarding the higher hierarchy as this involves the execution of less dangerous tasks. It is believed that the fact that it has not presented a high risk can be due to the fact that they involve less operational positions. In addition, we observed that even in population-based studies that resort to the same variables, differences might occur in view of the specific characteristics of each country and its labor legislation (Wong et al., 2011). Therefore, companies that have workers working in more than a job must have an even more effective follow-up policy to avoid accidents.

As for the variables of block 2, according to the data of Table 4.3, the occupational group was used in this study only for the purpose of interaction effect with the other variables. However, we emphasize that in the study by Rommel et al. (2016), from data collected in Germany for the occupational group, the authors resorted to categories such as administrative occupations, professions, engineers, managers, low level administrative and commercial occupations, semiprofessionals, technicians, high and low qualification services, manual occupations, agricultural jobs, among others.

When analyzing the variables of block 3 concerning physical stress, exposure to radiation was more likely to be prevalent, followed by prolonged exposure to sunlight. This type of work indicates that such professions more closely related to operational activities. The most commonly reported workrelated factors in the surveys were the hazards in the work system, work location, and workplace factors. Thus, the combination of these estimates represents the risk of accidents. Although model 5 did not present odds for occupational groups, it can be observed that, in model 1, some labor activities related to "farming, fishing, and forestry" $(\mathrm{OR}=9.827)$ require workers to be exposed to sunlight for long periods; Likewise, occupations related to the "production of industrial goods and services" ( $\mathrm{OR}=6.788)$ may involve activities with exposure to radiation. And if we relate this factor to the level of education, we infer that these activities are more pertinent to operational groups that involve these types of exposure to accidents. Therefore, according to Khanzode, Maiti, and Ray (2012), the risk can be perceived by combining 
several possible aspects. In addition, this is reinforced when handling of materials occur, which is one of the most common activities.

As for psychosocial stress, shift work was predominant (OR $=1.962)$. This case can be justified by the fact that such activities interrupt the circadian rhythm and increase fatigue. This change can cause disruption and can be more stressful mentally, physically and emotionally, leading to lack of concentration, which, in turn, increases the chances of accidents. Also, direct work supervision is more common at daytime, which may not occur during night shifts (Alali et al., 2017). Finally, working under pressure (OR $=1.294$ ) also showed prevalence chances. In fact, the results of the interaction between the work organization factors and the needs and experiences of workers make up the psychosocial factors and, if a given work condition is degrading, it is assumed that the worker is exposed to the risks (Lun Lu et al., 2014). Likewise, changes in the labor market deriving from innovation in production processes and technology generally imply in mental effort. Above all, the reduction of work placements generates overload. According to Nakata et al. (2006), this occurs for both men and women in all types of work, with a high quantitative workload and increased chances of occupational injuries.

Regarding block 4 of health-related factors, the results were mixed. Regarding the behavioral risk factors, alcohol consumption $(\mathrm{OR}=4.620)$ and obesity $(\mathrm{OR}=3.056)$ presented a significant likelihood of accidents. This result corroborates the study by Chau et al. (2009), as the authors reported that individual factors such as smoking, alcohol use, obesity, and poor health influence occupational injury rates. In turn, the use of alcohol reduces the reflex and balance of individuals, which can lead to accidents, especially when it comes to manual activities.

In the case of obese workers, they tend to be more at risk of falls. Furthermore, due to the environments with activities that have ergonomic demands, they have more difficulty in maintaining an adequate posture, a fact that increases the chances of accidents. Regarding this, studies indicate that obesity and lack of physical activity are related to prevalence, as in the study by Rommel et al. (2016), which identified that obesity and physical inactivity are the health-related factors that most impact the chances of accidents. Therefore, we understand that physical activity assists in the prevention of obesity and improves body flexibility, helping workers to tackle or escape from hazardous situations.

As for smoking ( $\mathrm{OR}=1.765)$, it is essential to emphasize the importance of prevention, since this habit causes disorders such as sleep disorders, 
cognitive impairment, may lead to fatigue and affects other physical functions. There is mainly a collective risk of accident, in view of the high risk of fire (Chau et al., 2009). Not all studies indicate smoking as a factor that increases the chances of accidents, but there are indications that such habit may be related to a specific social sphere, which is mainly explained by the socioeconomic factor, as is the use of alcohol (Rommel et al., 2016).

As for chronic conditions, asthma and diabetes had the highest risk odds (4,880 and 3,090, respectively). In fact, asthma is a chronic disease, and occupational environments are sources of exposure of inhalable agents that can trigger or aggravate the occurrence of injury to workers, especially among those who have been diagnosed by a physician. Diabetes, on the other hand, requires healthy habits such as regular meal schedules (Palmer, Harris, \& Coggon, 2008). The observance of these risk factors certainly creates opportunities for preventive measures and injury reduction programs. However, they demand programs that go beyond the requirements of the legislation regarding workplace safety and contemplate aspects of the workers' overall quality of life in organizations (Chau et al., 2009). In turn, depression, although statistically significant, showed a reduced chance of work-related accidents.

Considering the reasons exposed in this discussion, it was possible to confirm the hypotheses $\mathrm{H} 1$ and $\mathrm{H} 2$ postulated for this study, indicating a contribution to the explanation of work accidents, based on physical and psychosocial stress and health-related factors, as shown in the tables 3 and 4, from the sample analyzed. Therefore, the originality and the value of this research are revealed by its important findings, so that managers, as well as legislators interested in the prevention of work accidents, may observe the variables of greater representativeness more carefully, according to the blocks of factors presented, namely: block 1 (education level, full-time and long hours, having three or more jobs), block 3 (exposure to radiation and prolonged exposure to sunlight) and block 4 (asthma, alcohol consumption, obesity and diabetes), which were identified as factors that increase the chances of occurrence of occupational accidents.

In addition, the NHS was performed with a significant sample of the Brazilian population and the results used here provide subsidies for the causal explanation of diseases that can lead to illnesses and risks of accidents to which workers are subjected. In Brazil, the mortality rate due to accidents at work reaches 13.2 per 100,000 insured workers (Mascarenhas et al., 2015). In addition, work accidents represent about $7.3 \%$ of the benefits paid for by the Social Security Institute (Malta et al., 2017). It is also worth mentioning that the creation of the Brazilian legislation for the prevention 
of workplace accidents is an advance. Nonetheless, the country still needs to develop policies to reduce such a high rate, which places Brazil at the top of the ranking, along with other countries. Therefore, this study presents relevant results to assist in the planning and definition of intervention priorities within the scope of public policies, as well as in the private sphere.

\section{CONCLUSIONS}

The data obtained using the NHS sample, elaborated from the proposed and adapted models, (Rommel et al., 2016) recommend more significant attention from managers, both from the public and private spheres, who are interested in the challenges that involve the occurrence of workplace accidents. This subject is often understood in its entirety only when it reaches extreme levels, that is, when an accident leads to the death of workers. In addition, it is known that the history of work accidents indicates that there have been improvements. However, it has been reported that many accidents are not formally registered, which leads to an underreporting scenario. Therefore, actual data disclosed by the agencies in charge may be much larger than it is known.

Importantly, this study has contributed by reaching precise results on the most representative factors for the occurrence of work accidents in Brazil. It has also analyzed the associated physical and psychosocial stress, as well as the health-related factors. Summarizing the findings, it was found that the level of education, full-time and long hours, and having three or more jobs, listed in block 1 , are variables that point to a more significant propensity for work-related accidents. In addition, prolonged exposure to sunlight or radiation (block 3), when listed with the occurrence of asthma, alcohol consumption, obesity, and diabetes (block 4) were identified as factors that increase the chances of occupational accidents.

After the discussion, it can be inferred that the hypotheses postulated in this study have been confirmed, considering the interaction of the variables presented in the blocks in the models. This implies that physical and psychosocial stress and health-related factors deserve policies, programs, and actions specifically aimed at accident prevention. These measures should go beyond what the labor legislation establishes as some variables refer to aspects concerning the workers' everyday habits and routines, such as the practice of physical activity. In addition, companies that are pioneers in health and quality of life for workers have already implemented physical labor activities, weight control, healthy eating, ecological walks, among 
others in their daily routines, for the purpose of changing habits. As they are aware of their responsibility for the healthy life of their workers, they acknowledge that such measures generate more productivity and can reduce absenteeism.

Although this study has brought contributions, its limitations have been identified and dealt with below. As it is self-reported, bias can occur because it depends on the recollection of facts by the respondents, although they are more straightforward variables and do not require so much effort to be retrieved. In addition, reporting the circumstances in which accidents occurred could aggregate information about the factors associated with environmental exposure, for example, to understand the influence of poor physical conditions in the workplace, such as inadequate equipment, for instance. The type of accident, whether commuting or typical, has not been a variable of this study. However, this aspect can be analyzed to verify the influence of this type of accident and the relations with the different types of leave of absence. There are several databases in Brazil, but these are dispersed, which makes it difficult to obtain information as thoroughly as the German GEDA 2010.

Surveys conducted in other countries may comprise the research agenda to compare accident rates and health-related problems. Therefore, the studies on this subject are basically carried out in the health area, perhaps due to the familiarity with the databases and with the associated objects of study. However, although they have been conducted, there are still few studies in the area of management dealing with work accidents in order to identify factors such as those proposed here. In short, as another focus, this research could have discussed such factors, as well as the identification of organizational policies used to prevent injuries and accidents, as these directly affect the routine of organizations.

\section{ACIDENTES DE TRABALHO NO BRASIL: ANÁLISE DO ESTRESSE FÍSICO, PSICOSSOCIAL E FATORES RELACIONADOS À SAÚDE}

\section{RESUMO}

Proposta: Identificar a influência do estresse físico, psicossocial e fatores relacionados à saúde para a ocorrência de acidentes de trabalho, tendo 
como base a Pesquisa Nacional de Saúde (PNS) realizada em 2013 no Brasil, como reteste no contexto brasileiro, conforme o modelo de Rommel et al., (2016).

Originalidade/valor: No Brasil há um elevado índice de acidentes de trabalho. Este reteste aplicado ao contexto brasileiro a partir do modelo alemão de Rommel et al. (2016) possibilita apresentar informações em relação aos fatores com maior chance de ocorrência dos acidentes de trabalho.

Design/methodologia/abordagem: Estudo com dados secundários coletados da Pesquisa Nacional de Saúde (Fiocruz, 2013). Foi utilizado o modelo de Rommel et al. (2016) com o conjunto de quatro blocos de fatores de variáveis. A regressão logística explorou os fatores de estresse físico, psicossocial e relacionados à saúde que podem possuir mais chances para a ocorrência do acidente de trabalho.

Descobertas: 2,8\% dos indivíduos se envolveram em algum acidente de trabalho. O modelo 5 é o mais explicativo para os acidentes de trabalho e fatores como ensino médio (OR: 2,082), trabalho em período integral (OR: 4,814), três ou mais trabalhos (OR: 2,593), exposição radioativa (OR: 4,244), asma (OR: 4,880) e, consumo de álcool (OR:4,620) foram identificados como aqueles com maior chance, conforme cada bloco tipificado, para a ocorrência do acidente de trabalho. Os gestores e legisladores devem observar os fatores que atribuem mais chances para a ocorrência de acidentes para a elaboração de políticas ou ações de prevenção.

\section{PALAVRAS-CHAVE}

Acidente de trabalho. Estresse físico. Estresse psicossocial. Fatores de saúde. Ocupação.

\section{REFERENCES}

Alali, H., Braeckman, L., Van Hecke, T., De Clercq, B., Janssens, H., \& Wahab, M. (2017). Relationship between non-standard work arrangements and workrelated accident absence in Belgium. Journal Occupational Health, 59(2), 177-186. doi:10.1539/joh.16-0119-OA 
Ministério da Fazenda. (2015). Anuário Estatístico da Previdência Social. Brasília: MF/DATAPREV.

Areosa, J., Dwyer, T. (2010). Acidentes de trabalho: Uma abordagem sociológica. Revista de Sociologia Configurações, 7, 107-128.

Associação Brasileira para o Estudo da Obesidade e da Síndrome Metabólica. (2009). Diretrizes brasileiras de obesidade - 2009/2010. Itapevi: Abeso. Retrieved from http://www.abeso.org.br/pdf/diretrizes_brasileiras obesidade_2009_2010_1.pdf

Berecki-Gisolf, J., Smith, P. M., Collie, A., \& McClure, R. J. (2015). Gender differences in occupational injury incidence. American Journal of Industrial Medicine, 58(3), 299-307. doi:10.1002/ajim.22414

Brazil. (1991). Lei no 8.213, de 24 de julho de 1991. Diário Oficial da União. Retrieved from http://www.planalto.gov.br/ccivil_03/leis/L8213cons.htm

Bureau of Labor Statistics. (2016). National census of fatal occupational injuries in 2015. Washington: United States Department of Labor. Retrieved from https://www.bls.gov/news.release/archives/cfoi_1216 2016.pdf

Cavalcante, C. A. A., Medeiros, S. M. de, Mata, M. de S., Cavalcante, E. F. de O., Cavalcante, E. S., \& Oliveira, L. V. (2015). Serious work accidents in Rio Grande do Norte: A cross sectional study. Online Brazilian Journal of Nursing, 14(4). doi:10.17665/1676-4285.20155221

Chau, N., Bhattacherjee, A., Kunar, B. M., \& Lorhandicap, G. (2009). Relationship between job, lifestyle, age and occupational injuries. Occupational Medicine, 59(2). doi:10.1093/occmed/kqp002

Damacena, G. N., Szwarcwald, C. L., Malta, D. C., Souza Jr., P. R. B. de, Vieira, M. L. F. P., Pereira, C. A., .. . Silva Jr., J. B. da. (2015). O processo de desenvolvimento da Pesquisa Nacional de Saúde no Brasil - 2013. Epidemiologia eServiçosem Saúde,24(2), 197-206.doi:10.5123/S1679-49742015000200002

Dembe, A., Erickson, J. B., Delbos, R. G., \& Banks, S. M. (2005). The impact of overtime and long work hours on occupational injuries and illnesses: New evidence from the United States. Occupational Environmental Medicine, 62, 588-597. doi:10.1136/oem.2004.016667

Dong, X. W. S., Wang, X. W., \& Largay, J. A. (2015). Occupational and non occupational factors associated with work-related injuries among construction workers in the USA. International Journal Occupational Environmental Health, 37(1), 142-150. doi:10.1179/2049396714Y.0000000107 
Duarte, M. E., Soares, M. C, Fraga, S., Rafael, M., Lima, M. R., Paredes, I., . . . Djaló, A. (2012). Career Adapt-Abilities Scale - Portugal form: Psychometric properties and relationships to employment status. Journal of Vocational Behavior, 80(3), 725-729. doi:10.1016/j.jvb.2012.01.019

Fahel, M. (2003). A configuração dos riscos ambientais e de saúde: Um olhar desde a perspectiva das desigualdades sociais. In C. A. Salin, L. F. de Carvalho; M. N. de C. Freitas, \& M. de Freitas, Saúde e segurança no trabalho: Novos olhares e saberes. Belo Horizonte: Fundacentro.

Fiocruz. (2013). Pesquisa nacional de saúde. Retrieved from www.pns.fiocruz.br Guimarães, L. A. M., \& Grubits, S. (2004). Série saúde mental e trabalho (Vol. 1). São Paulo: Casa do Psicólogo.

Hair Jr., J. H., Black, W. C., Babin, B. J, Anderson, R. E., \& Tatham, R. L. (2005). Análise multivariada de dados ( $5^{\text {th }}$ ed.). Porto Alegre: Bookman.

Instituto Brasileiro de Geografia e Estatística. (2017)

Jex, S. M. (1998). Stress and job performance: Theory, research, and implications for managerial practice. Thousand Oaks, CA: Sage Publications.

Khanzode, V., Maiti, J., \& Ray, P. (2012). Occupational injury and accident research: A comprehensive review. Safety Science, 50(5), 1355-1367. doi:10.1016/j.ssci.2011.12.015

Lotufo, J. P. Tabagismo, uma doença pediátrica. São Paulo: Savier, 2007.

Lun Lu, M., Nakata, A., Park, J. B., Naomi, G., Swanson, N. G. (2014). Workplace psychosocial factors associated with work-related injury absence: A study from a nationally representative sample of Korean workers. International Journal Behavioral Medicine, 21, 42-52. doi:10.1007/ s12529-013-9325-y

Macedo, R. B. (2008). Segurança, saúde, higiene e medicina do trabalho. Curitiba: Iesde Brasil S.A.

Mascarenhas, M. D. M, Freitas, M. G. F., Monteiro, R. A. M., Silva, M. M. A., Malta, D. C. M., \& Gomez, M. G. (2015). Atendimentos de emergência por lesões relacionadas ao trabalho: características e fatores associados - capitais e Distrito Federal, Brasil, 2011. Ciência \& Saúde Coletiva, 20(3), 667-678. doi:10.1590/1413-81232015203.16842014

Malta, D. C., Stopa, S. R., Silva, M. M. A., Szwarcwald, C. L., Franco, M. S. F., Santos, F. V., . . . Gomez, C. M. (2017). Acidentes de trabalho autorreferidos pela população adulta brasileira, segundo dados da Pesquisa Nacional de Saúde, 2013. Ciências E Saúde Coletiva, 22 (1), 169-178. doi:10.1590/141381232017221.17862015 
Nakata, A., Ikeda, T., Takahashi, M., Haratani, T., Hojou, M., Fujioka, Y., . . . Araki, S. (2006). Impact of psychosocial job stress on non-fatal occupational injuries in small and medium-sized manufacturing enterprises. American Journal of Industrial Medicine, 49(8), 658-69. doi:10.1002/ajim.20338

Palmer, K. T., Harris, E. C., \& Coggon, D. (2008) Chronic health problems and risk of accidental injury in the workplace: A systematic literature review. Occupational and environmental medicine, 65(11), 757-764. doi:10.11 36/oem.2007.037440

Pan, A., Schernhammer, E. S., Sun, Q., \& Hu, F. B. (2011). Rotating night shift work and risk of type 2 diabetes: Two prospective cohort studies in women. PLOS Medicine, 8(12), e1001141. doi:10.1371/journal.pmed.100 1141

Paschoal, T., \& Tamayo, A. (2004). Validação da escala de estresse no trabalho. Estudos de Psicologia, 9(1), 45-52. doi:10.1590/S1413-294X20040001 00006

Paixão, M. P. C. P., Paixão, S. J. P., \& Franco, L. R. (2009) Obesidade como fator de risco para acidentes no trabalho. Revista Saúde e Pesquisa, 2(3), 379-386.

Pedersen, B., Hannerz, H., Christensen, U., \& Tüchsen, F. (2011). Enterprise size and risk of hospital treated injuries among manual construction workers in Denmark: A study protocol. Journal of Occupational Medicine and Toxicology, 6(11). doi:10.1186/1745-6673-6-11

Piha, K., Laaksonen, M., Martikainen, P., Rahkonen, O., \& Lahelma, E. (2012). Socio-economic and occupational determinants of work injury absence. European Journal Public Health, 23(4), 693-698. doi:10.1093/ eurpub/cks162

Rodrigues, L. B., \& Santana, N. B. (2010). Identificação de riscos ocupacionais em uma indústria de sorvete. Unopar Científica - Ciências Biológicas e da Saúde, 12(3), 31-38.

Rommel, A., Varnaccia, G., Lahmann, N., Kottner, J., \& Kroll, L. E. (2016). Occupational injuries in Germany: Population-wide national survey data emphasize the importance of work-related factors. PLOS One, 11(2). doi:10.1371/journal.pone.0148798

Santana, V. S, Araújo-Filho, J. B., Albuquerque-Oliveira, P. A., \& Barbosa-Branco, A. (2006). Acidentes de trabalho: Custos previdenciários e dias de trabalho perdidos. Revista de Saúde Pública, 40(6), 1004-1012. doi:10.1590/ S0034-89102006000700007

Snell, S., Bohlander, G. (2009). Administração de recursos humanos. São Paulo: Cengage Learning. 
Statistical Package for the Social Sciences (Version 20.0) [Computer software]. São Paulo, SP: Brazil.

Szwarcwald, C. L., Malta, D. C., Pereira, C. A., Vieira, M. L. F. P., Conde, W. L., Souza Jr., P. R. B., . . Monteiro, C. A. (2014). Pesquisa Nacional de Saúde no Brasil: Concepção e metodologia de aplicação. Ciências \& Saúde Coletiva, 19(2), 333-342. doi:10.1590/1413-81232014192.14072012

Wong, I. S., McLeod, C. B., \& Demers, P. A. (2011). Shift work trends and risk of work injury among Canadian workers. Scandinavian Journal of Work Environment \& Health, 37(1), 54-61. doi:10.5271/sjweh.3124

World Health Organization. (2016). Overweight and obesity. Retrieved from http://www.who.int/gho/ncd/risk_factors/overweight_obesity/bmi_ trends_adults/en/

\section{AUTHOR NOTE}

Simarly M. Soares, Business Administration, Fundação Cultural Dr. Pedro Leopoldo; Simone Gelmini, Business Administration, Fundação Cultural Dr. Pedro Leopoldo; Silvânia S. S. Brandão, Business Administration, Fundação Cultural Dr. Pedro Leopoldo; June M. C. Silva, Business Administration, Universidade Estaudal de Montes Claros.

Simarly M. Soares and Simone Gelmini are now PhD candidates at Universidade de Brasília and Teachers at Universidade Estadual de Montes Claros; Silvânia S. S. Brandão is now the higher education Coordinator and Teacher at Faculdade Prisma; and June M. C. Silva is now a Teacher at Universidade Estadual de Montes Claros.

Correspondence concerning this article should be adressed to Simarly M. Soares, Avenida Dr. Ruy Braga, s/n, Montes Claros, MG, Brazil, CEP 39401-089.

E-mail: simarly@gmail.com

EDITORIAL BOARD

Editor-in-chief

Silvio Popadiuk

Associated Editor

Fabiano Larentis

(iD) https://orcid.org/0000-0001-8390-0271

Technical Support

Vitória Batista Santos Silva
EDITORIAL PRODUCTION

$\begin{array}{ll}\begin{array}{l}\text { Publishing Coordination } \\ \text { Irina Migliari }\end{array} & \begin{array}{l}\text { Language Editor } \\ \text { Daniel Leão }\end{array} \\ \text { Editorial Trainee } & \text { Layout Designer } \\ \text { Maria Luiza Vanz } & \text { Emap } \\ \text { Copyeditor } & \text { Graphic Designer } \\ \text { Irina Migliari } & \text { Libro }\end{array}$

